http://dx.doi.org/10.11646/phytotaxa.201.1.7

\title{
Considerations on the genus Schizachyrium (Poaceae-Andropogoneae) in Central America and West Indies, and confirmation of the occurrence of $S$. glaziovii
}

\author{
CASSIANO A. DORNELES WELKER ${ }^{1} \&$ MYRIAM CAROLINA PEICHOTO ${ }^{2}$ \\ ${ }^{1}$ Universidade Federal do Rio Grande do Sul, Programa de Pós-Graduação em Botânica, Av. Bento Gonçalves 9500, Porto Alegre, Rio \\ Grande do Sul,91501-970,_Brazil.E-mail: cassiano_welker@yahoo.com.br \\ ${ }_{2}^{2}$ Instituto de Botánica del Nordeste, Facultad de Ciencias Agrarias (UNNE), Sargento Cabral 2131, Corrientes, 3400, Argentina. \\ E-mail:mcpeichoto@agr.unne.edu.ar
}

\begin{abstract}
Schizachyrium (Poaceae-Andropogoneae) includes ca. 60 species, 10 of them previously cited for Central America and 13 for West Indies. The confirmation of the occurrence of Schizachyrium glaziovii in these regions is reported here, expanding its northern limit of distribution to Guatemala and Belize. The species was previously accepted only for South America. We provide a description of the species, a distribution map, and a key to distinguish it from $S$. microstachyum and $S$. condensatum, species whose circumscriptions are confused in floras of Central America and West Indies. Taxonomic comments, illustrations of the type materials and images of the three species are also provided. A revised synonymy of $S$. glaziovii is presented and a lectotype for Andropogon condensatus subsp. elongatus (a synonym of Schizachyrium glaziovii) is designated here.
\end{abstract}

Key words: Gramineae, lectotypification, Mesoamerica, Schizachyrium condensatum, Schizachyrium microstachyum

\section{Resumen}

Schizachyrium (Poaceae-Andropogoneae) incluye cerca de 60 especies, 10 de las cuales fueron previamente citadas para América Central y 13 especies para las Indias Occidentales. En este trabajo se reporta la presencia de Schizachyrium glaziovii para esa región, expandiendo su límite Norte hasta Guatemala y Bélice. Esta especie fue previamente aceptada solamente para Sudamérica. Se proporciona la descripción de la especie, el mapa de distribución y una clave para distinguirla de $S$. microstachyum y $S$. condensatum, especies cuyas circunscripciones son muy confusas en las floras de América Central e Indias Occidentales. También se incluyen comentarios taxonómicos, ilustraciones del material tipo y fotografías de las tres especies. Se presenta la sinonimia revisada de $S$. glaziovii y se designa aquí el lectotipo de Andropogon condensatus subsp. elongatus (sinónimo de Schizachyrium glaziovii).

Palabras clave: Gramineae, lectotipificación, Mesoamérica, Schizachyrium condensatum, Schizachyrium microstachyum

\section{Introduction}

Schizachyrium Nees (1829: 331) (Poaceae-Andropogoneae) includes ca. 60 species from tropical and subtropical regions of the world (Clayton \& Renvoize 1986). The genus is represented in America by ca. 30 species, distributed from Canada to Argentina and Uruguay (Filgueiras 2003). Ten species have been cited for Central America: eight of them for Guatemala, six for Belize, Costa Rica, Honduras, and Nicaragua, five for Panama, and four for El Salvador (Manrique 1994, Pohl 1994, Filgueiras 2003). Thirteen species have been cited for West Indies (Hitchcock 1936, Filgueiras 2003) (Table 1).

The species of Schizachyrium have been divided into two morphological groups, based on inflorescence traits (Peichoto et al. 2008). The first group includes taxa with straight rachis internodes and pedicels, and sparsely branched inflorescences with one to a few racemes. The other group includes taxa with flexuous rachis internodes and pedicels at maturity, and highly branched inflorescences, like S. condensatum (Kunth 1816: 188) Nees (1829: 333) and related species. A molecular phylogeny of Schizachyrium is being performed in order to test the monophyly of the genus and of these two morphological groups of species (Peichoto et al. in prep.). No molecular phylogeny of the genus is currently available. Türpe (1984) accepted $S$. condensatum in a broad sense, considering as its synonyms almost all 


\section{References}

Alston, A.H.G. (1931) In: Trimen, H. (Ed.) A hand-book to the flora of Ceylon vol 6. Dulau \& Co., London, pp. 1-350. http://dx.doi.org/10.5962/bhl.title.10864

Borhidi, A.L. \& Catasús Guerra, L.J. (1980) In: Borhidi, A.L. (Ed.) New names and new species in the flora of Cuba, II. Acta Botanica Academiae Scientiarum Hungaricae 26: 255-275.

Büse, L.H. (1854) Gramineae. In: Miquel, F.A.W. (Ed.) Plantae junghuhnianae: enumeratio plantarum, quas, in insulis Java et Sumatra. A.W. Sythoff, Leiden, pp. 341-394.

http://dx.doi.org/10.5962/bhl.title.388

Clayton, W.D. \& Renvoize, S.A. (1986) Genera graminum: grasses of the world. Her Majesty's Stationery Office, London, 389 pp.

D'Arcy, W.G. (1987) Flora of Panama: checklist and index. Part I: The introduction and checklist. Monographs in Systematic Botany from the Missouri Botanical Garden 17: 1-328.

Filgueiras, T.S. (2003) Schizachyrium Nees. In: Zuloaga, F.O., Morrone, O., Davidse, G., Filgueiras, T.S., Peterson, P.M., Soreng, R.J. \& Judziewicz, E.J. (Eds.) Catalogue of New World grasses (Poaceae): III. Subfamilies Panicoideae, Aristidoideae, Arundinoideae and Danthonioideae. Contributions from the United States National Herbarium 46: 560-569.

Hackel, E. (1883) Gramineae IV., Andropogoneae, Tristegineae. In: Martius, C.F.P. \& Eichler, A.G. (Eds.) Flora Brasiliensis, vol. 2, pt. 3. F. Fleischer, Monachii, pp. 245-342. http://dx.doi.org/10.5962/bhl.title.454

Hackel, E. (1885) Andropogoneae novae. Flora 68: 115-128.

Hackel, E. (1889) Andropogoneae. In: De Candolle, A. \& De Candolle, C. (Eds.) Monographiae phanerogamarum, vol. 6. Sumptibus G. Masson, Paris, pp. 1-716. http://dx.doi.org/10.5962/bhl.title.45961

Hackel, E. (1906) Segunda contribución al conocimiento de las gramináceas argentinas. Anales del Museo Nacional de Buenos Aires 3 : 409-555.

Hamilton, W. (1825) Prodromus plantarum Indiae Occidentalis. Treuttel \& Würtz, London, 67 pp. http://dx.doi.org/10.5962/bhl.title.426

Herter, W.G. (1940) Plantae uruguayenses novae vel criticae. Revista Sudamericana de Botánica 6: 129-155.

Hitchcock, A.S. (1936) Manual of the grasses of the West Indies. United States Government Printing Office, Washington D.C., 439 pp. http://dx.doi.org/10.5962/bhl.title.65543

Hitchcock, A.S. \& Ekman, E.L. (1936) In: Hitchcock, A.S. (Ed.) Manual of the grasses of the West Indies. United States Government Printing Office, Washington D.C., pp. 390. http://dx.doi.org/10.5962/bhl.title.65543

Kunth, C.S. (1816) Nova genera et species plantarum. In: Humboldt, F.W.H.A., Bonpland, A.J.A. \& Kunth, C.S. (Eds.) Voyage de Humboldt et Bonpland vol 6, Botanique. Sumtibus Librariae Graeco-Latino-Germanicae, Paris, pp. 1-377. http://dx.doi.org/10.5962/bhl.title.640

Manrique, E.A. (1994) The genus Schizachyrium in Mexico and Central America. Texas A\&M University, College Station, 165 pp.

Morales, J.F. (2003) Poaceae. In: Hammel, B.E., Grayum, M.H., Herrera, C. \& Zamora, N. (Eds.) Manual de plantas de Costa Rica: Monocotiledóneas (Orchidaceae-Zingiberaceae), vol. III. Monographs in Systematic Botany from the Missouri Botanical Garden 93: 598-821.

http://dx.doi.org/10.5962/bhl.title.891

Nash, G.V. (1903) Poaceae. In: Small, J.K. (Ed.) Flora of the Southeastern United States. Published by the author, New York, pp. 48161.

http://dx.doi.org/10.5962/bhl.title.133

Nash, G.V. (1912) Poaceae. In: Britton, N.L., Murrill, W.A. \& Barnhart, J.H. (Eds.) North American flora, vol. 17, pt. 2. The New York Botanical Garden, New York, pp. 99-196.

Nees, C.G. (1829) Agrostologia brasiliensis. In: Martius, C.F.P. (Ed.) Flora Brasiliensis seu enumeratio plantarum, vol. 2. J.G. Cottae, Stuttgart \& Tübingen, pp. 1-608.

Nelson Sutherland, C.H. (2008) Catálogo de las plantas vasculares de Honduras: Espermatofitas. Secretaría de Recursos Naturales y Ambiente, Tegucigalpa, 1576 pp.

Peichoto, M.C. (2010) Revisión taxonómica de las especies del género Schizachyrium (Poaceae: Andropogoneae) de Sudamérica. Candollea 65: 301-346. http://dx.doi.org/10.15553/c2010v652a9

Peichoto, M.C., Mazza, S.M. \& Neffa, V.G.S. (2008) Morphometric analysis of Schizachyrium condensatum (Poaceae) and related species. 
Plant Systematics and Evolution 276: 177-189.

http://dx.doi.org/10.1007/s00606-008-0076-1

Pohl, R.W. (1994) Schizachyrium Nees. In: Davidse, G., Sousa S., M. \& Chater, A.O. (Eds.) Flora Mesoamericana: Alismataceae a Cyperaceae, vol. 6. Universidad Nacional Autónoma de México, México, pp. 391-393.

Pohl, R.W. (2001) Schizachyrium Nees. In: Stevens, W.D., Ulloa, C.U., Pool, A. \& Montiel, O.M. (Eds.) Flora de Nicaragua: Angiospermas (Pandanaceae-Zygophyllaceae), vol. III. Monographs in Systematic Botany from the Missouri Botanical Garden 85: $2125-2127$.

Presl, J.S. (1830) Gramineae. In: Presl, C.B. (Ed.) Reliquiae Haenkeanae, vol. 1, fasc. 4-5. Apud J.G. Calve, Pragae, pp. $207-349$. http://dx.doi.org/10.5962/bhl.title.515

Reeder, J.R. (1984) A new record for Schizachyrium semitectum in Mexico. Phytologia 55: 252.

Retzius, A.J. (1783) Observationes botanicae. Siegfried Lebrecht Crusium, Leipzig, 286 pp.

Roberty, G. (1960) Monographie systématique des Andropogonées du globe. Boissiera 9: 1-455.

Rosengurtt, B., Arrillaga de Maffei, B.R. \& Izaguirre de Artucio, P. (1968) Especies nuevas y notas taxonómicas de gramíneas en Uruguay y Paraguay. Las especies afines a Schizachyrium condensatum de Uruguay y Paraguay. Boletín Facultad de Agronomía Montevideo 103: 25-41.

Sprengel, C.P.J. (1824) Systema vegetabilium, vol. 1. Sumtibus Librariae Dieterichianae, Göttingen, 992 pp. http://dx.doi.org/10.5962/bhl.title.822

Steudel, E.G. (1854) Synopsis plantarum glumacearum, vol. 1. J.B. Metzler, Stuttgart, 475 pp. http://dx.doi.org/10.5962/bhl.title.471

Swallen, J.R. (1950) New grasses from Mexico, Central America, and Surinam. Contributions from the United States National Herbarium 29: 395-428.

Swallen, J.R. (1955) Flora of Guatemala. Part II: grasses of Guatemala. Fieldiana, Botany 24: 1-390. http://dx.doi.org/10.5962/bhl.title.2328

Swartz, O. (1788) Nova genera et species plantarum seu prodromus. Holmiae, Stockholm, 158 pp. http://dx.doi.org/10.5962/bhl.title.433

Türpe, A.M. (1984) Revision of the South American species of Schizachyrium (Gramineae). Kew Bulletin 39: 169-178. http://dx.doi.org/10.2307/4107867

Welker, C.A.D. \& Longhi-Wagner, H.M. (2012a) New records in Schizachyrium (Poaceae-Andropogoneae) for Rio Grande do Sul and for Brazil. Rodriguésia 63: 1147-1150. http://dx.doi.org/10.1590/S2175-78602012000400025

Welker, C.A.D. \& Longhi-Wagner, H.M. (2012b) Sinopse do gênero Schizachyrium Nees (Poaceae-Andropogoneae) no estado do Rio Grande do Sul, Brasil. Iheringia, Série Botânica 67: 199-223.

Wooton, E.O. \& Standley, P.C. (1912) The grasses and grass-like plants of New Mexico. New Mexico Agricultural Experiment Station: Bulletin 81: 1-175.

http://dx.doi.org/10.5962/bhl.title. 15352

\section{Appendix}

Additional material examined

Schizachyrium condensatum (Kunth) Nees (Figs. 1A-C, 2A-B).

Type:-COLOMBIA. Tolima, regni novogranatensis, prope Ibague \& Valle de Carabajal, October, Humboldt \& Bonpland s.n. (holotype $\mathrm{P}$ !, isotype US! [fragm. ex P]).

Schizachyrium microstachyum (Desv. ex Ham.) Roseng., B.R. Arrill. \& Izag. (Figs. 1H-K, 2E-F).

Type:-WEST INDIES. Desvaux 8 (holotype P!, isotype US! [fragm. ex P]).

A large number of specimens of Schizachyrium condensatum and S. microstachyum from different countries was also examined. These herbarium specimens are listed in Peichoto (2010) and Welker \& Longhi-Wagner (2012b). 